\title{
Single-ion interferences when using magnetic microparticles for phosphorus removal in aquatic ecosystems
}

\author{
A. Merino-Martos ${ }^{1,2}$, J. de Vicente ${ }^{3}$, L. Cruz-Pizarro ${ }^{1,2}$ and I. de Vicente ${ }^{1,2, *}$ \\ ${ }^{1}$ Departamento de Ecología, Facultad de Ciencias, Universidad de Granada, 18071 Spain. \\ ${ }^{2}$ Instituto del Agua, Universidad de Granada, 18071 Spain. \\ ${ }^{3}$ Departamento de Física Aplicada, Facultad de Ciencias, Universidad de Granada, 18071 Spain. \\ * Corresponding author: ivicente@ugr.es
}

Received: 9/04/2014 Accepted: 30/10/2014

\begin{abstract}
Single-ion interferences when using magnetic microparticles for phosphorus removal in aquatic ecosystems

The specific adsorption of phosphate $(\mathrm{P})$ on strongly magnetisable carbonyl iron (Fe) particles and their subsequent removal by in-flow High Gradient Magnetic Separation (HGMS) is considered a promising tool for restoring eutrophied waters. A previous study showed the existence of chemical interferences in natural waters without considering the influence of specific major ions on the P removal efficiency (de Vicente et al., 2011). Therefore, in this manuscript, we assess the single-effect of some of the major ions present in natural waters, including sulphate $\left(\mathrm{SO}_{4}^{2-}\right)$, calcium $\left(\mathrm{Ca}^{2+}\right)$, humic acid $(\mathrm{HA}$, as an indicator of Dissolved Organic Carbon, DOC), and reactive silicate ( $\mathrm{Si}$ ), on $\mathrm{P}$ adsorption to magnetic Fe particles in artificial lake water. The results showed that $\mathrm{HA}$ and Si significantly decreased the effectiveness of $\mathrm{P}$ adsorption by magnetic Fe particles. In particular, P removal efficiency decreased to $12 \%$ and $22 \%$ when $\mathrm{HA}$ and Si concentrations were $35.5 \mathrm{mg} \mathrm{HA} \mathrm{L}{ }^{-1}$ and $10 \mathrm{mg} \mathrm{Si} \mathrm{L}{ }^{-1}$, respectively. By contrast, $\mathrm{SO}_{4}^{2-}$ and $\mathrm{Ca}^{2+}$ did not significantly reduce $\mathrm{P}$ removal. We recommend chemically analysing the lake water and determining the $\mathrm{Fe}$ dosage that obtains the highest $\mathrm{P}$ removal before using magnetic particles for the restoration of aquatic ecosystems in a whole-lake application.
\end{abstract}

Key words: Phosphate removal, magnetic particles, High Gradient Magnetic Separation, chemical interferences.

\section{RESUMEN}

Interferencias químicas asociadas a la presencia de un único ión cuando se utilizan micropartículas magnéticas para la eliminación de fósforo en ecosistemas acuáticos

$L a$ adsorción específica del fosfato $(P)$ sobre partículas, fuertemente magnetizables, de hierro carbonilo $(F e)$, y su posterior retirada del medio usando técnicas de Separación Magnética de Alto Gradiente (HGMS), bajo condiciones de flujo continuo, está siendo considerada como una herramienta prometedora para restaurar ecosistemas acuáticos eutrofizados. Un estudio previo puso de manifiesto la existencia de interferencias químicas en aguas naturales, reduciendo, así, la eficiencia en la retirada del $P$ pero ese estudio no pudo explicar el efecto directo que tenía cada ión en la eficiencia en la retirada del $P$ (de Vicente et al., 2011). En base a esto, en este trabajo hemos evaluado el efecto individual de algunos de los iones mayoritarios presentes en las aguas naturales tales como el sulfato $\left(\mathrm{SO}_{4}^{2-}\right)$ y el calcio $\left(\mathrm{Ca}^{2+}\right)$ así como los ácido húmicos (HA) y la sílice (Si), en la adsorción del P sobre las partículas magnéticas de Fe. Los resultados han mostrado que los HA (usado como un indicador del DOC) y el Si decrecen significativamente la adsorción del P por las partículas magnéticas de Fe. En particular, la eficiencia en la retirada del P decreció a un $12 \%$ y un $22 \%$ cuando las concentraciones de HA y Si eran de $35.5 \mathrm{mg} H \mathrm{~A}$

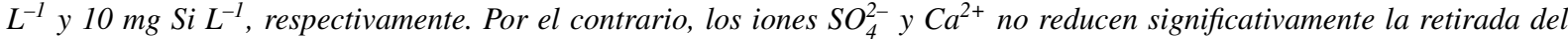
$P$ por la adsorción sobre las partículas magnéticas de Fe. Por todo ello, se recomienda que antes de usar las partículas magnéticas para restaurar ecosistemas acuáticos eutrofizados es esencial hacer un análisis químico del agua del lago para poder determinar la dosis más adecuada de Fe y conseguir, así, la mayor eficiencia en la retirada del P.

Palabras clave: Eliminación de fósforo, partículas magnéticas, Separación Magnética de Alto Gradiente, interferencias químicas. 


\section{INTRODUCTION}

Eutrophication is one of the most important and long lasting water quality problems in the European Union. For at least two decades now, several policies have been adopted to tackle nutrient pollution and its consequences. The Water Framework Directive (WFD, 2000/60/EC) established an integrated and coordinated framework for the sustainable management of water, including the prevention of the deterioration of water bodies (lakes, rivers, coastal and transitional, groundwater), the promotion of sustainable water use, and ensuring the "enhanced protection and improvement of the aquatic environment." This last point requires that rivers, lakes, estuaries, coastal waters and groundwater achieve and/or maintain at least a 'good status' by 2015.

Eutrophication is mainly caused by excessive inorganic nutrient loading (e.g., Hupfer \& Hilt, 2008). In particular, phosphorus (P) has been identified as the main nutrient responsible for eutrophication (Hupfer \& Hilt, 2008; Jeppesen et al., 2009; Smith, 2009). Concurrently, the demand for good quality freshwater is increasing and this makes the development of new and efficient technologies for removing $\mathrm{P}$ from aqueous solutions an important challenge for limnologists and for water resource managers (Jeppesen et al., 2009). Hence, new adsorbents were developed in the last decadefor the treatment of polluted water (Hsu et al., 2008; Panther et al., 2011; Zhang et $a l ., 2011$ ). Of these adsorbents, aluminium (Al) compounds are increasingly being used for trapping $\mathrm{P}$ in lake sediments (e.g., Smeltzer et al., 1999; Welch \& Cooke, 1999; Reitzel et al., 2005; Egemose et al., 2011; Reitzel et al., 2013a). They adsorb and precipitate both phosphate $\left(\mathrm{PO}_{3}^{4-}\right)$ and dissolved organic P-compounds (Reitzel et al., 2009), but the resulting Al phases and floc quality are $\mathrm{pH}$ dependent, showing the highest efficiency when $\mathrm{pH}$ is in the range 6 to 8 (e.g., Kennedy \& Cooke, 1982). Phoslock is another promising $\mathrm{P}$ adsorbent (Robb et al., 2003; Reitzel et al., 2013b, 2013c). It is made from modified bentonite clay containing an active P-adsorbing rare earth ingredient Lanthanum (La) within its chemical structure. Phoslock is most effective at $\mathrm{pH}$ values between 5 and 7, and the adsorption capacity decreases above $\mathrm{pH} 9$ (Ross et al., 2008). Additionally, natural and modified zeolites, consisting of a three-dimensional framework structure bearing $\mathrm{SiO}_{4}$ and $\mathrm{AlO}_{4}$ tetrahedral, have recently been used for $\mathrm{P}$ removal from an aqueous solution (e.g., Karapinar, 2009; Gibbs \& Özkundakci, 2011). They were demonstrated to be highly effective P-inactivation agents under both aerobic and anaerobic conditions.

In addition to these novel effective adsorbents, an alternative technology based on the use of magnetic particles could be considered for lake restoration (de Vicente et al., 2010; de Vicente et al., 2011; Merino-Martos et al., 2011). Two outstanding advantages of using these particles for lake restoration, as previously suggested, are (i) the recovery of magnetic particles from the solution, reducing any effects on the aquatic biota and (ii) the reusability of the particles, thus reducing economic costs. In this context, the high $\mathrm{P}$ adsorption capacity of micron-sized carbonyl iron particles was tested under batch conditions, and the most favourable working conditions were identified by de Vicente et al. (2010). Later on, Merino-Martos et al. (2011) set up a laboratory-scale device for separating $\mathrm{P}$ from water under continuous flow conditions by using High Gradient Magnetic Separation (HGMS), which allows the handling large volumes of water because of decreasing retention times. In brief, this method is based on the use of highly magnetisable particles as the seeding adsorbent material and their later removal from solution by HGMS. Finally, and considering that $\mathrm{Fe}$ oxides have been previously used for removing colour, turbidity and metals for water clarification (Chang et al., 2004; Dixon, 1984; Girginova et al., 2010) and chemical interferences in $\mathrm{P}$ removal by magnetic seeding in natural waters were studied by de Vicente et al. (2011). In particular, these authors reported chemical interferences affecting $\mathrm{P}$ removal efficiencies in natural waters from 20 Mediterranean ponds and reservoirs. Their results showed that high $\mathrm{P}$ removal efficiencies $(>80 \%)$ were found in freshwater lakes (conductivities $<600 \mu \mathrm{S} \mathrm{cm}^{-1}$ ), while $\mathrm{P}$ 
removal was very small $(20 \%)$ in extremely high mineralised waters. Although a correlation analysis showed that major cations $\left(\mathrm{Mg}^{2+}, \mathrm{Na}^{+}\right.$ and $\left.\mathrm{K}^{+}\right)$and anions $\left(\mathrm{SO}_{4}^{2-}\right.$ and $\left.\mathrm{Cl}^{-}\right)$were the driving factors controlling the effectiveness of $\mathrm{P}$ removal, these experiments could not determine whether anions or cations by themselves were able to reduce $\mathrm{P}$ removal efficiency or, if by contrast, the observed inefficiency was just an indirect consequence of the significant correlation between cation and anion concentrations. As a result, further experimental research using specific anions in artificial lake water is needed.

The main aim of the present study was to improve our knowledge about the effectiveness of $\mathrm{P}$ adsorption on carbonyl iron particles in the presence of relevant specific ions. To achieve this goal, we ran a set of laboratory single-ion experiments in artificial lake water and increased the specific ion concentration. In particular, we studied the effect of humic acid, sulphate, silicate and calcium on $\mathrm{P}$ removal efficiency by magnetic particles using the in-flow HGMS technique. In order to quantify single-ion interferences when adding magnetic particles, it was a preliminary task to determine the appropriate $\mathrm{Fe}$ dose to achieve the highest $\mathrm{P}$ removal efficiency.

\section{MATERIAL AND METHODS}

\section{Preparation of magnetic particles, phosphate and specific-ion solutions}

Fe suspensions were prepared by dispersing $5 \mathrm{~g}$ $\mathrm{Fe}$ of carbonyl iron powder (BASF, Germany) particles in $100 \mathrm{~mL}$ distilled $\mathrm{H}_{2} \mathrm{O}$. The physicochemical properties and elemental compositions of these particles were described by de Vicente $e t$ al. (2010).

A stock $1 \mathrm{mM} \mathrm{P}$ solution was prepared by adding $136 \mathrm{mg} \mathrm{KH} \mathrm{KO}_{4}$ (Panreac, Spain) to $1 \mathrm{~L}$ of distilled water.

Humic acid (HA), from Sigma-Aldrich, was used as a simulator of lake dissolved organic carbon (DOC). The content of carboxylic groups of this particular humic acid is approximately $3.1 \mathrm{mmol} / \mathrm{g}$ (de Vicente et al., 2008). The HA stock solution was prepared by the addition of $1.4 \mathrm{~g}$ humic acid to $1 \mathrm{~L} 3 \mathrm{mM} \mathrm{NaHCO}$ solution and the $\mathrm{pH}$ was adjusted to 8.5 (de Vicente et al., 2008). The stock solution was stirred for 12 hours and filtered through fibre filters (Whatman GF/C) to remove residual non-dissolved humic acid powder. The amount of DOC in the filtered solution was measured by High-Temperature Catalytic Oxidation on a Schimadzu TOC-V CSH. The final DOC concentration in the HA stock solution was $35.5 \mathrm{mg} / \mathrm{L}$.

A stock sulphate solution was prepared by adding $18.14 \mathrm{~g} \mathrm{~K}_{2} \mathrm{SO}_{4}$ (Panreac, Spain) to $1 \mathrm{~L}$ distilled water. The final $\mathrm{SO}_{4}^{2-}$ concentration was $10000 \mathrm{mg} / \mathrm{L}$. Commercially available standard solutions of silicate and calcium (Merck, Spain) with concentrations of $1000 \mathrm{mg} / \mathrm{L}$ were used.

\section{Laboratory experiments}

A set of laboratory single-ion experiments was conducted to study the interference of specific ions on $\mathrm{PO}_{4}^{3-}$ adsorption by carbonyl Fe particles. Each test consisted of adding $2 \mathrm{~mL}$ of the stock Fe solution $(50 \mathrm{~g} / \mathrm{L})$ and $2 \mathrm{~mL}$ of the $\mathrm{P}$ solution (1 mM) to $100 \mathrm{~mL}$ volumetric flasks. Afterwards, different aliquots of the specific-ion solutions were added to give a desired final concentration. The $\mathrm{pH}$ of the samples was adjusted to $\mathrm{pH}=7$ with the addition of $\mathrm{HCl} 1 \mathrm{M}$ or $\mathrm{NaOH} 1 \mathrm{M}$ and left shaking overnight. After $24 \mathrm{~h}$, the $\mathrm{pH}$ was again re-adjusted to $\mathrm{pH}=7$, and suspensions were finally transferred to $100 \mathrm{~mL}$ volumetric flasks, making the total volume $3 \mathrm{mM} \mathrm{NaHCO}$. The $\mathrm{Fe} / \mathrm{P}$ concentrations ratios used in all of the treatments were those identified by MerinoMartos et al. (2011) as necessary for achieving the highest $\mathrm{P}$ removal efficiency.

- Testing the interference with humic acid: For testing the effect of HA on $\mathrm{P}$ removal efficiency, two suspensions with different concentrations of $\mathrm{HA}$ (17 and $35.5 \mathrm{mg} \mathrm{C} \mathrm{L}^{-1}$ ) were prepared. The first suspension was obtained by adding $2 \mathrm{~mL}$ of the stock Fe solution $(50 \mathrm{~g} / \mathrm{L})$ and $2 \mathrm{~mL}$ of $\mathrm{P}$ solution $(1 \mathrm{mM})$ to $100 \mathrm{~mL}$ of the HA stock solution, for a final HA concentration of $35.5 \mathrm{mg} \mathrm{C} \mathrm{L}^{-1}$. The second 
suspension was obtained by using $50 \mathrm{~mL}$ of the $\mathrm{HA}$ stock solution and adding $\mathrm{NaHCO}_{3}$ up to $100 \mathrm{~mL}$, for a final HA concentration of $17 \mathrm{mg}$ $\mathrm{C} \mathrm{L}^{-1}$. The suspensions were then passed through the HGMS as described below, and $\mathrm{PO}_{4}^{3-}$ was quantified in the filtered samples.

- Testing the interference with sulphate: Different aliquots $(1,2.5,5,10$ and $50 \mathrm{~mL})$ of the stock $\mathrm{SO}_{4}^{2-}$ solution were added to different magnetic suspensions (containing $2 \mathrm{~mL}$ of the $50 \mathrm{~g} \mathrm{Fe} \mathrm{L}^{-1}$ and $2 \mathrm{~mL}$ of $1 \mathrm{mM} P$ solution in $100 \mathrm{~mL} \mathrm{NaHCO} 3$ ) to yield final $\mathrm{SO}_{4}^{2-}$ concentrations of 100, 250, 500, 1000 and $5000 \mathrm{mg} / \mathrm{L}$, respectively. The suspensions were treated as described below, and the filtered samples were analysed for $\mathrm{PO}_{4}^{3-}$ and $\mathrm{SO}_{4}^{2-}$.

- Testing the interference with silicate: Different aliquots $(0.5,1,2.5$ and $5 \mathrm{~mL})$ of the stock silicate solution were added to each magnetic suspension and prepared as previously described. The final silicate concentrations were 5, 10, 25 and $50 \mathrm{mg} / \mathrm{L}$. The suspensions were treated as described below, and the filtered samples were analysed for $\mathrm{PO}_{4}^{3-}$ and dissolved reactive silicate $(\mathrm{Si})$.

- Testing the interference with calcium: Different aliquots $(1,5,10$ and $50 \mathrm{~mL})$ of the stock $\mathrm{Ca}^{2+}$ solution were added to each magnetic suspension and prepared as previously described. The final $\mathrm{Ca}^{2+}$ concentrations were 10, 50, 100 and $500 \mathrm{mg} / \mathrm{L}$. Each sample was subjected to HGMS treatment described below, and the filtered samples were analysed for $\mathrm{PO}_{4}^{3-}$ and $\mathrm{Ca}^{2+}$.

The experimental set-up was similar for all of the competitive adsorption tests. An axial HGMS filter was used through which $\mathrm{Fe}+\mathrm{P}+$ single-ion suspensions were passed by using a peristaltic pump (Watson Marlow 205S). More details on the theoretical background of the axial HGMS filter design and the standard protocol can be found in Merino-Martos et al. (2011). Briefly, $\mathrm{Fe}+\mathrm{P}+$ ion suspensions were first sonicated and then passed through the axial HGMS filter. The experiments were performed
Table 1. Effect of HA on $P$ removal efficiency, including standard deviations (SD). The values reported are the average of the three replicates. Efecto de los ácidos húmicos (HA) sobre la eficiencia en la retirada de $P$, incluye la desviación estándar $(S D)$. Los valores mostrados son la media aritmética de las tres réplicas.

\begin{tabular}{ccc}
\hline $\mathrm{HA}\left(\mathrm{mg} \mathrm{C} \mathrm{L}^{-1}\right)$ & P removal $(\%)$ & $\mathrm{SD}$ \\
\hline 0 & 97.0 & 1.3 \\
17 & 94 & 9 \\
35.5 & 12 & 7 \\
\hline
\end{tabular}

under optimal conditions with a sonication time $=5 \mathrm{~min}$, flow rate $=0.36 \mathrm{~mL} / \mathrm{s}$, and the $\mathrm{Fe} / \mathrm{P}$ concentration ratio $=3.22$. The magnetic field strength in the filter was fixed at $450 \mathrm{kA} / \mathrm{m}$. The treated samples coming from the HGMS device were filtered through a fibre filter (Whatman GFF) and $\mathrm{P}, \mathrm{Si}, \mathrm{SO}_{4}^{2-}$ and $\mathrm{Ca}^{2+}$ concentrations were determined in the filtered samples. In particular, equilibrium $\mathrm{P}$ concentrations were determined using the spectrophotometric method described by Murphy \& Riley (1962). The dissolved reactive silicate $(\mathrm{Si})$ was determined by using a spectrophotometric method described by Koroleff (1983). The determination of calcium $\left(\mathrm{Ca}^{2+}\right)$ and sulphates $\left(\mathrm{SO}_{4}^{2-}\right)$ was performed by ionic chromatography (DIONEX DX300) after filtering the samples (Millipore, $0.22 \mu \mathrm{m}$ ). Samples for dissolved organic carbon (DOC) analyses were collected after filtration through pre-combusted Whatman GF/F filters into precombusted $30 \mathrm{~mL}$ glass ampoules, acidified with hydrochloric acid (final $\mathrm{pH}=2$ ), sealed and stored at $4{ }^{\circ} \mathrm{C}$ until the analysis. The DOC was analysed by high-temperature catalytic oxidation on a Shimadzu TOC-V CSH.

Finally, to examine the effect of $\mathrm{HA}, \mathrm{SO}_{4}^{2-}, \mathrm{Si}$ and $\mathrm{Ca}^{2+}$ on carbonyl $\mathrm{Fe}$ particles, an adsorption experiment similar to the experiment described above was conducted without adding $\mathrm{PO}_{4}^{3-}$.

\section{Statistical analysis}

All of the experiments were carried out in triplicates. The mean values were compared using Student's t-test and, unless otherwise stated, $p<0.05$ was considered statistically significant. The statistical analyses were performed using Statistica 6.0 Software. 


\section{RESULTS AND DISCUSSION}

\section{Effect of humic acid on $P$ adsorption by carbonyl Fe particles}

To study the interferences of HA on P adsorption by magnetic Fe particles, we analysed changes in the $\mathrm{P}$ removal efficiency in the presence of different HA concentrations (17 and $35.5 \mathrm{mg} / \mathrm{L}$ ). Single-ion experiments showed a significant reduction in $\mathrm{P}$ adsorption by $\mathrm{Fe}$ particles in the presence of the highest HA concentrations $(35.5 \mathrm{mg} / \mathrm{L})$. In fact, the $\mathrm{P}$ removal efficiency decreased from $94 \%$ to $12 \%$ when HA concentrations increased from 17 to $35.5 \mathrm{mg} / \mathrm{L}$ (Table 1).

From these results, we concluded that the organic molecules of HA were more likely to have a greater preference for adsorption sites of Fe particles rather than $\mathrm{P}$ particles at higher concentrations of HA. This conclusion emerges from the fact that acidic functional groups of HA are able to act as ligands in a ligand exchange reaction on the oxide surface that is consistent with the specific adsorption mechanism in $\mathrm{P}$ adsorption on $\mathrm{Fe}$ particles. Consequently, there is strong competition between $\mathrm{P}$ and $\mathrm{HA}$ for adsorption sites on $\mathrm{Fe}$ particles (de Vicente et al., 2011).

The adsorption of HA on Fe oxides has been widely reported in literature and it is known that $\mathrm{HA}$ can bind metals over the entire $\mathrm{pH}$ range (Zhang et al., 2009a). Cornell \& Schwertmann (1996) and Schindler (1990) reported that the adsorption of organic ligands predominated in
pH's below the point of zero charge (pzc) of the oxide dominating the electrostatic effects. However, ligand exchange and hydrophobic bonding may also be involved at pH's above the pzc. More recently, Illés \& Tombácz (2004, 2006) investigated the $\mathrm{pH}$-dependent adsorption of HA on magnetite and revealed that the adsorption capacity was severely influenced by $\mathrm{pH}$ and ionic strength. Their experiments demonstrated that the amount of adsorbed HA was greater under acidic conditions, although at basic pH's, notable amounts of HA were also adsorbed in accordance with previous literature.

Similar findings have been observed for other oxides and hydroxides. Sibanda \& Young (1986) observed that organic matter in solution strongly decreased $\mathrm{P}$ adsorption by aluminium and iron oxides, and particularly of low $\mathrm{pH}$ soils. For instance, using single-ion experiments, de Vicente et al. (2008) found a noteworthy reduction in $\mathrm{P}$ adsorption to $\mathrm{Al}(\mathrm{OH})_{3}$ by the presence of HA. More recently, Zhang et al. (2009b) indicated the reduction in the $\mathrm{P}$ removal efficiency through the addition of natural organic matter (NOM) in a suspension with iron oxide nanoparticles. They justified this conclusion by the fact that NOM adsorption can impart a negative charge to nanoparticle surfaces and increase their surface electrostatic potentials.

However, there are also publications that demonstrated negligible interactions between $\mathrm{HA}$ and $\mathrm{P}$ adsorption. For example, Borggaard $e t$ al. $(1990,2005)$ studied the effects of HA and

Table 2. Results of $\mathrm{P}$ removal and $\mathrm{SO}_{4}^{2-}$ removal by magnetic Fe particles, at different initial concentrations of $\mathrm{SO}_{4}^{2-}$, in the presence and absence of $\mathrm{P}$. The values reported are the averages of the three replicates. Resultados de la retirada de $\mathrm{P}$ y de $\mathrm{SO}_{4}^{2-}$ mediante las partículas de Fe a diferentes concentraciones iniciales de $\mathrm{SO}_{4}^{2-}$, en presencia y en ausencia de P. Los valores mostrados son la media aritmética de las tres réplicas.

\begin{tabular}{ccccccc}
\hline \multicolumn{9}{c}{$\mathrm{P}+\mathrm{Fe}+\mathrm{SO}_{4}^{2-}$} \\
\hline $\begin{array}{c}\mathrm{SO}_{4}^{2-} \\
(\mathrm{mg} / \mathrm{L})\end{array}$ & $\begin{array}{c}\mathrm{PO}_{4}^{3-} \\
\text { removal }(\%)\end{array}$ & $\begin{array}{c}\mathrm{PO}_{4}^{3-} \text { removal } \\
(\mathrm{mg} \mathrm{P} / \mathrm{g} \mathrm{Fe})\end{array}$ & $\begin{array}{c}\mathrm{SO}_{4}^{2-} \\
\text { removal }(\%)\end{array}$ & $\begin{array}{c}\mathrm{SO}_{4}^{2-} \text { removal } \\
\left(\mathrm{mg} \mathrm{SO}_{4}^{2-} / \mathrm{g} \mathrm{Fe}\right)\end{array}$ & $\begin{array}{c}\mathrm{SO}_{4}^{2-} \\
\mathrm{removal}(\%)\end{array}$ & $\begin{array}{c}\mathrm{SO}_{4}^{2-} \\
\left(\mathrm{mg} \mathrm{SO} \mathrm{SO}_{4}^{2-} / \mathrm{g} \mathrm{Fe}\right)\end{array}$ \\
\hline 100 & $100.0 \pm 0.3$ & $15.06 \pm 0.05$ & $0 \pm 30$ & $0 \pm 30$ & $44 \pm 10$ & $37 \pm 8$ \\
250 & $98.4 \pm 1.9$ & $14.8 \pm 0.3$ & $6.6 \pm 1.2$ & $18 \pm 3$ & $3.8 \pm 1.7$ & $10 \pm 5$ \\
500 & $96 \pm 6$ & $14.4 \pm 0.9$ & $6.8 \pm 0.9$ & $37 \pm 5$ & $5.54 \pm 0.18$ & $30 \pm 1$ \\
1000 & $94 \pm 3$ & $14.1 \pm 0.5$ & $4.4 \pm 0.9$ & $45 \pm 9$ & $9.1 \pm 4$ & $69 \pm 8$ \\
5000 & $92 \pm 4$ & $13.8 \pm 0.6$ & $3.8 \pm 1.5$ & $210 \pm 80$ & $8 \pm 5$ & $600 \pm 40$ \\
\hline
\end{tabular}


fulvic acids on $\mathrm{P}$ adsorption by aluminium and iron oxides in soil samples and found that organic matter did not compete with $\mathrm{P}$ for adsorption sites of oxides. This observation is similar to that previously described by Gerke \& Hermann (1992) that reported P bonding onto humic-Fe complexes via ligand exchange by the substitution of $\mathrm{H}_{2} \mathrm{O}$ and $\mathrm{OH}^{-}$. This reaction was found to be dependent upon $\mathrm{pH}$, as well as the presence of $\mathrm{Ca}^{2+}$ ions. $\mathrm{Ca}^{2+}$ adsorbed on negative charged groups reduces electrostatic repulsion of the $\mathrm{P}$ anions and, therefore, $\mathrm{P}$ adsorption is increased at a $\mathrm{pH}$ above 5.2.

\section{Effect of sulphate ions on $P$ adsorption by carbonyl Fe particles}

Using a combination of solutions $\left(\mathrm{Fe}+\mathrm{P}+\mathrm{SO}_{4}^{2-}\right.$ and $\mathrm{Fe}+\mathrm{SO}_{4}^{2-}$ ), we observed that there was not a significant $(p>0.05)$ effect of $\mathrm{SO}_{4}^{2-}$ anions on $\mathrm{P}$ adsorption by magnetic $\mathrm{Fe}$ particles (Table 2). In fact, an increase in $\mathrm{SO}_{4}^{2-}$ concentrations from 100 to $5000 \mathrm{mg} / \mathrm{L}$ caused a slight, but not significant, reduction in the $\mathrm{P}$ removal efficiency (from $100 \%$ to $92 \%$ ). These results were consistent with other data reported in the literature on iron oxides (Zhang et al., 2009a; Geelhoed et al., 1997). Geelhoed et al. (1997) found that the presence of $\mathrm{SO}_{4}^{2-}$ caused only a small reduction in $\mathrm{P}$ adsorption per surface area unit of goethite. Zhang et al. (2009a) found that the presence of $\mathrm{SO}_{4}^{2-}$ had no significant effect on $\mathrm{P}$ removal by a Fe-Mn binary oxide adsorbent. Notable differences existed, however, between our experimental design and that by Zhang et al. (2009a). For example, we used a much lower initial $\mathrm{P}$ concentration $(0.62 \mathrm{mg} / \mathrm{L}$ instead of $5 \mathrm{mg} / \mathrm{L})$ and much higher $\mathrm{SO}_{4}^{2-}$ concentrations (from 100 to $5000 \mathrm{mg} / \mathrm{L}$ instead of from 96 to $960 \mathrm{mg} / \mathrm{L}$ ) than Zhang et al. (2009a). This means that even in our scenario with low $\mathrm{P}$ and high $\mathrm{SO}_{4}^{2-}$ concentrations, which was more likely to determine the existence of chemical interference, no significant interactions occurred.

Our results also showed that adsorption of $\mathrm{SO}_{4}^{2-}$ by magnetic Fe particles was strongly controlled by the presence or absence of $\mathrm{P}$ in the solution (Table 2). Hence, for the highest $\mathrm{SO}_{4}^{2-}$ concentration, a three-fold significant increase in $\mathrm{SO}_{4}^{2-}$ removal (in $\mathrm{mg} \mathrm{SO}_{4}^{2-} \mathrm{g}^{-1} \mathrm{Fe}$ ) was measured when no $\mathrm{P}$ was in the solution compared to when the $\mathrm{P}$ concentration was higher than $100 \mathrm{mg} / \mathrm{L}$. Our results were consistent with those reported by Geelhoed et al. (1997), who observed that $\mathrm{P}$ experienced a higher affinity for adsorption sites on goethite than $\mathrm{SO}_{4}^{2-}$ over a wide range of $\mathrm{pH}$ $(2.5,4.0,5.5,7.0$ and 8.5) and, therefore, is a stronger competitor. It is important to note that adsorption of $\mathrm{SO}_{4}^{2-}$ by $\mathrm{Fe}$ oxides may be nonspecific involving ion pair formation and dominated by electrostatic interaction (Cornell \& Schwertmann, 1996). In fact, $\mathrm{SO}_{4}^{2-}$ adsorption strongly depends on the $\mathrm{pH}$, with adsorption being the highest at a low $\mathrm{pH}$ and decreasing when the $\mathrm{pH}$ rises, up to a negligible adsorption above the pzc (Cornell \& Schwertmann, 1996). In this sense, it is important to emphasise that all of our experiments were run at $\mathrm{pH} 7$ and that de Vicente et al. (2010) measured an isoelectric point (i.e.p) of the carbonyl $\mathrm{Fe}$ particles of approximately 6.5, so at $\mathrm{pH} 7$ only minor adsorption of $\mathrm{SO}_{4}^{2-}$ ions by $\mathrm{Fe}$ particles can be expected. Also in agreement with our results, Boukhalfa (2010) found that $\mathrm{SO}_{4}^{2-}$ removal from aqueous solutions by hydrous Fe oxide was very dependent on the presence of P. Nevertheless, it is important to note that Boukhalfa used extremely high $\mathrm{P}$ concentrations (500 times higher than ours: $10 \mathrm{mM}$ instead of $20 \mu \mathrm{M})$. This author found a noteworthy reduction in $\mathrm{SO}_{4}^{2-}$ adsorption when the concentration of $\mathrm{P}$ increased from $2.5 \mathrm{mM}$ to $10 \mathrm{mM}$ $(\mathrm{pH}=3-8)$. Even more, at $\mathrm{pH}$ above 6 , no adsorption of $\mathrm{SO}_{4}^{2-}$ was observed for $10 \mathrm{mM}$ concentration as a result of the strong interaction of $\mathrm{P}$ with the surface of the hydroxide relatively to $\mathrm{SO}_{4}^{2-}$. In summary, these results were explained by the fact that both of the ions competed for the same sorption sites.

\section{Effect of silicate on $P$ adsorption by carbonyl Fe particles}

Single-ion experiments using $\mathrm{Fe}+\mathrm{P}+\mathrm{Si}$ and $\mathrm{Fe}+\mathrm{Si}$ suspensions were conducted to test the effectiveness of $\mathrm{P}$ adsorption by magnetic $\mathrm{Fe}$ particles in the presence of $\mathrm{Si}$. Our results 
showed that a significant reduction in $\mathrm{P}$ adsorption by $\mathrm{Fe}$ particles occurred when the $\mathrm{Si}$ concentration increases (Table 3 ). In fact, the $\mathrm{P}$ removal efficiency was reduced from $81 \%$ to $35 \%$ when the Si concentration increased from 5 to $50 \mathrm{mg} / \mathrm{L}$. These findings were consistent with previous studies which noted that $\mathrm{Si}$ and $\mathrm{P}$ had the same specific adsorption behaviour, and competition for adsorption sites should occur (Sigg \& Stumm, 1981; Cornell \& Schwertmann, 1996; Hartikainen et al., 1996). A similar behaviour was observed by de Vicente et al. (2008) when using $\mathrm{Al}(\mathrm{OH})_{3}$ as the $\mathrm{P}$ adsorbent. These authors concluded that $\mathrm{Si}$ (at similar concentrations used in the present study) significantly decreased the effectiveness of $\mathrm{P}$ adsorption by $\mathrm{Al}(\mathrm{OH})_{3}$ in single-ion experiments. More recently, Egemose et al. (2011) observed that after Al treatment to a eutrophic lake (Lake Nordborg, Denmark), silicate regeneration from the sediment was reduced by $69 \%-76 \%$ and consequently, lake water silicate concentration decreased by $87 \%$. Our results were also consistent with those obtained by Hartikainen et al. (1996), who analysed sediment samples from Lake Vesijärvi (southern Finland). These authors observed that $\mathrm{P}$ oxyanions competed directly with $\mathrm{Si}$ compounds for sorption sites, but their results indicated that Si retention on the oxide surface was less effective than that of P. They justified it as a result of the high $\mathrm{pK}_{a}$ value of silicic acid (9.7), which implied that $\mathrm{Si}$ sorption is at maximum at a $\mathrm{pH}$ above 9. Again, it is important to note that our experiments were performed at $\mathrm{pH} \mathrm{7,} \mathrm{therefore,} \mathrm{Si}$ ions were expected to be less adsorbed by $\mathrm{Fe}$ particles than P (Hartikainen, 1996). Sigg \& Stumm (1981) reported the dependence of $\mathrm{pK}$ values on the surface charge of $\alpha-\mathrm{FeOOH}$ (goethite). They investigated the adsorption of several ions, including $\mathrm{Si}$, on the surface of goethite and observed that $\mathrm{Si}$ is adsorbed over a wide $\mathrm{pH}$ range with a maximum near $\mathrm{pH} 9$. Furthermore, Meng et al. (2000) observed that Si significantly decreased Arsenite removal, an anion with a similar chemical behaviour as $\mathrm{P}$, when the $\mathrm{Si}$ concentration was higher than $1 \mathrm{mg} / \mathrm{L}$ and the $\mathrm{pH}$ was greater than 5 . For example, they found that in the presence of $10 \mathrm{mg} / \mathrm{L} \mathrm{Si}$ and a $\mathrm{pH}$ of approximately 6.8 , the adsorption capacity of ferric hydroxide for Arsenite was reduced from $116 \mu \mathrm{g} / \mathrm{mg}$ to $23 \mu \mathrm{g} / \mathrm{mg} \mathrm{Fe}$.

For completeness, we also investigated the adsorption behaviour of Si by magnetic Fe particles in the presence and absence of $\mathrm{P}$ (Table 3). We found that $\mathrm{Si}$ removal was at all Si concentrations significantly lower in the presence $(\mathrm{P}+\mathrm{Fe}+\mathrm{Si})$ than in the absence $(\mathrm{Fe}+\mathrm{Si})$ of $\mathrm{P}$. These results, together with the drastic reduction in $\mathrm{P}$ removal in the presence of $\mathrm{Si}$, again confirm the existence of a strong competition for adsorption sites on Fe particles. We have also fit our experimental data, from experiments $\mathrm{Si}+\mathrm{Fe}$ and $\mathrm{Si}+\mathrm{Fe}+\mathrm{P}$, to a linear regression line reaching values for $r^{2}$ higher than 0.8. Our results showed that for an initial Si concentration of $10 \mathrm{mg} \mathrm{L}^{-1}$, Si removal decreased from $12.2 \%$ to $8.2 \%$ in the presence of $10 \mu \mathrm{M}$ P. However, if we compare $\mathrm{P}$ and $\mathrm{Si}$ removal, we could conclude that despite the competition among both anions, $\mathrm{P}$ is clearly preferentially adsorbed by Fe particles (Table 3). For ex-

Table 3. Results of P removal and Si removal by magnetic Fe particles, at different initial concentrations of Si, in the presence and in the absence of $\mathrm{P}$. The values reported are the averages of the three replicates. Resultados de la retirada de P y de Si mediante las partículas de Fe a diferentes concentraciones iniciales de Si, en presencia y en ausencia de P. Los valores mostrados son la media aritmética de las tres réplicas.

\begin{tabular}{|c|c|c|c|c|c|c|}
\hline \multicolumn{5}{|c|}{$\mathrm{P}+\mathrm{Fe}+\mathrm{Si}$} & \multicolumn{2}{|c|}{$\mathrm{Fe}+\mathrm{Si}$} \\
\hline $\begin{array}{c}\mathrm{Si} \\
(\mathrm{mg} / \mathrm{L})\end{array}$ & $\begin{array}{c}\mathrm{PO}_{4}^{3-} \\
\text { removal }(\%)\end{array}$ & $\begin{array}{c}\mathrm{PO}_{4}^{3-} \text { removal } \\
(\mathrm{mg} \mathrm{P} / \mathrm{g} \mathrm{Fe})\end{array}$ & $\begin{array}{c}\mathrm{Si} \\
\text { removal }(\%)\end{array}$ & $\begin{array}{c}\text { Si removal } \\
(\mathrm{mg} \mathrm{Si} / \mathrm{g} \mathrm{Fe})\end{array}$ & $\begin{array}{c}\mathrm{Si} \\
\text { removal }(\%)\end{array}$ & $\begin{array}{c}\text { Si removal } \\
(\mathrm{mg} \mathrm{Si} / \mathrm{g} \mathrm{Fe})\end{array}$ \\
\hline 5 & $81 \pm 9$ & $22 \pm 2$ & $12 \pm 9$ & $0.6 \pm 0.5$ & $14 \pm 5$ & $0.7 \pm 0.3$ \\
\hline 10 & $22 \pm 4$ & $6.1 \pm 1.2$ & $6.3 \pm 1.8$ & $0.65 \pm 0.19$ & $12 \pm 4$ & $1.3 \pm 0.4$ \\
\hline 25 & $24 \pm 4$ & $4.2 \pm 0.8$ & $3.3 \pm 1.6$ & $0.8 \pm 0.4$ & $7 \pm 6$ & $1.6 \pm 1.4$ \\
\hline 50 & $35 \pm 12$ & $6 \pm 2$ & $0.3 \pm 0.5$ & $0.2 \pm 0.2$ & $4.2 \pm 1.0$ & $2.0 \pm 0.5$ \\
\hline
\end{tabular}


ample, at an initial Si concentration of $10 \mathrm{mg} / \mathrm{L}, \mathrm{P}$ removal was significantly higher $(22 \%, 6.1 \mathrm{mg} \mathrm{P}$ $\left.\mathrm{g}^{-1} \mathrm{Fe}\right)$ than $\mathrm{Si}$ removal $\left(6.3 \%, 0.6 \mathrm{mg} \mathrm{Si} \mathrm{g}^{-1} \mathrm{Fe}\right)$.

In general, it is important to note that in most natural waters the $\mathrm{Si}$ concentration is below $10 \mathrm{mg} / \mathrm{L}$. In fact, an extensive survey performed by de Vicente et al. (2011) in 20 inland aquatic ecosystems with widely differing chemical composition revealed that 19 of $20 \mathrm{Si}$ concentrations were below $10 \mathrm{mg} / \mathrm{L}$ and that 17 of 20 presented Si concentrations lower than $5 \mathrm{mg} / \mathrm{L}$. Therefore, according to Table 3, for such a low $\mathrm{Si}$ concentration, only minor competition is likely to occur between $\mathrm{P}$ and $\mathrm{Si}$. For those cases where $\mathrm{Si}$ concentration is higher, it is essential to consider Si competition in order to dose the right amount of Fe particles for the adsorption of $\mathrm{P}$.

\section{Effect of calcium ions on $P$ adsorption by carbonyl Fe particles}

To assess the role of $\mathrm{Ca}^{2+}$ ions in controlling the effectiveness of $\mathrm{P}$ removal by $\mathrm{Fe}$ particles, single-ion experiments were performed using $\mathrm{Fe}+\mathrm{P}+\mathrm{Ca}^{2+}$ suspensions. The results showed that $\mathrm{Ca}^{2+}$ did not significantly affect the $\mathrm{P}$ removal efficiency by Fe particles, denoting no competition for adsorption sites (Table 4). In fact, in a wide $\mathrm{Ca}^{2+}$ concentration range $(10-500 \mathrm{mg} / \mathrm{L})$ resembling the $\mathrm{Ca}^{2+}$ concentration in inland waters typical of Southeastern Spain (i.e., de Vicente et al., 2011), the P removal efficiency was always higher than $93 \%$.

Stachowicz et al. (2008) studied the interaction between $\mathrm{Ca}^{2+}-\mathrm{PO}_{4}^{3-}$ and $\mathrm{Mg}^{2+}-\mathrm{PO}_{4}^{3-}$ on goethite. Specifically, in the $\mathrm{Ca}^{2+}-\mathrm{PO}_{4}^{3-}$, they found that $\mathrm{P}$ adsorption existed, as well as $\mathrm{Ca}^{2+}$ adsorption in a $\mathrm{pH}$ range $3-11$, in spite of the fact that $\mathrm{Ca}^{2+}$ had a much lower affinity for goethite than $\mathrm{PO}_{4}^{3-}$. This result was explained by the electrostatic interactions, as the negative charges of the adsorbed $\mathrm{PO}_{4}^{3-}$ ions on goethite stimulated the binding of the positively charged $\mathrm{Ca}^{2+}$ ion. However, contrary to these observations, we have not found any $\mathrm{Ca}^{2+}$ removal by Fe particles in the presence of $\mathrm{P}$ (Table 4$)$.

The formation of mixed metal/ligand surface complexes may occur and promote the adsorption of ions (Balistrieri \& Murray, 1982; Cornell \& Schwertmann, 1996; Gao \& Mucci, 2003; de Vicente et al., 2011). Nevertheless, adsorption behaviour can be affected by factors such as $\mathrm{pH}$, concentrations and ionic strength (Kim \& Walker, 2001). It was reported in the literature that the extent of adsorption of cations on $\mathrm{Fe}$ oxides depended on pH (Dixon, 1984). Indeed, there was a narrow $\mathrm{pH}$ range where the adsorption of cations went from near zero adsorption to $100 \%$ adsorption, and this is commonly called the adsorption edge (Balistieri \& Murray, 1982). For example, Gao \& Mucci (2003) observed that the addition of $\mathrm{Ca}^{2+}$ increased $\mathrm{P}$ adsorption on goethite slightly at $\mathrm{pH}<8.5$ and extensively at $\mathrm{pH}>9 . \mathrm{Ca}^{2+}$ cations adsorb on goethite and render the $\mathrm{Fe}$ oxides surface more positively charged, promoting $\mathrm{P}$ adsorption. Again, we have to note that all of the experiments were run at $\mathrm{pH}=7$, so a secondary effect of $\mathrm{Ca}^{2+}$ on $\mathrm{P}$ removal occurred in our experiments.

Next, we aimed to study the $\mathrm{Ca}^{2+}$ adsorption by the Fe particles both in the presence and in the absence of $\mathrm{P}$ (Table 4). Although we have

Table 4. Results of $\mathrm{P}$ removal and Ca removal by magnetic Fe particles, at different initial concentrations of Ca, in the presence and in the absence of $\mathrm{P}$. The values reported are the averages of the three replicates. Resultados de la retirada de P y de Ca mediante las partículas de Fe a diferentes concentraciones iniciales de Ca, en presencia y en ausencia de P. Los valores mostrados son la media aritmética de las tres réplicas.

\begin{tabular}{|c|c|c|c|c|c|c|}
\hline \multicolumn{5}{|c|}{$\mathrm{Fe}+\mathrm{P}+\mathrm{Ca}^{2+}$} & \multicolumn{2}{|c|}{$\mathrm{Fe}+\mathrm{Ca}^{2+}$} \\
\hline $\begin{array}{c}\mathrm{Ca}^{2+} \\
(\mathrm{mg} / \mathrm{L})\end{array}$ & $\begin{array}{c}\mathrm{PO}_{4}^{3-} \\
\text { removal }(\%)\end{array}$ & $\begin{array}{c}\mathrm{PO}_{4}^{3-} \text { removal } \\
(\mathrm{mg} \mathrm{P} / \mathrm{g} \mathrm{Fe})\end{array}$ & $\begin{array}{c}\mathrm{Ca}^{2+} \\
\text { removal }(\%)\end{array}$ & $\begin{array}{l}\mathrm{Ca}^{2+} \text { removal } \\
\left(\mathrm{mg} \mathrm{Ca}^{2+} / \mathrm{g} \mathrm{Fe}\right)\end{array}$ & $\begin{array}{c}\mathrm{Ca}^{2+} \\
\text { removal }(\%)\end{array}$ & $\begin{array}{l}\mathrm{Ca}^{2+} \text { removal } \\
\left(\mathrm{mg} \mathrm{Ca}^{2+} / \mathrm{g} \mathrm{Fe}\right)\end{array}$ \\
\hline 10 & $96 \pm 4$ & $16.8 \pm 0.7$ & $0 \pm 4$ & $0.0 \pm 0.2$ & $59.6 \pm 1.1$ & $3.11 \pm 0.06$ \\
\hline 50 & $100.0 \pm 0.3$ & $17.5 \pm 0.1$ & $0.0 \pm 1.7$ & $0.0 \pm 0.4$ & $0 \pm 10$ & $0 \pm 2$ \\
\hline 100 & $100.0 \pm 0.3$ & $17.5 \pm 0.1$ & $0 \pm 3$ & $0.0 \pm 1.6$ & $0.0 \pm 1.7$ & $0.0 \pm 0.9$ \\
\hline 500 & $93 \pm 6$ & $16 \pm 1$ & $0 \pm 3$ & $0 \pm 8$ & $17 \pm 4$ & $52 \pm 14$ \\
\hline
\end{tabular}


not found a clear tendency as a function of $\mathrm{Ca}^{2+}$ concentrations, the $\mathrm{Ca}^{2+}$ removal was generally higher when $\mathrm{P}$ was not present in the solution. In particular, for the highest $\mathrm{Ca}^{2+}$ concentration $(500 \mathrm{mg} / \mathrm{L})$, the mean $\mathrm{Ca}^{2+}$ removal was $52 \mathrm{mg} \mathrm{Ca} \mathrm{g}^{-1} \mathrm{Fe}$ in the absence of P. No $\mathrm{Ca}^{2+}$ removal was achieved in the presence of P. Gao \& Mucci (2003) studied $\mathrm{Ca}^{2+}$ adsorption on goethite in the absence of $\mathrm{P}$ and found that the $\mathrm{Ca}^{2+}$ adsorption was zero at $\mathrm{pH}=7.5$, but it increased to close to $50 \%$ at $\mathrm{pH}=10$. Again, it is important to note that cation adsorption not only depends on $\mathrm{pH}$ but also on ionic strength. For example, Gao \& Mucci (2003) compared P adsorption on goethite in a $0.7 \mathrm{M} \mathrm{NaCl}$ solution and an artificial seawater solution. They found that $\mathrm{P}$ adsorption was slightly lower in the $0.7 \mathrm{M} \mathrm{NaCl}$ solution when compared to the artificial seawater.

\section{CONCLUSIONS}

This study showed that the main drivers of $\mathrm{P}$ removal by adsorption on magnetic carbonyl iron microparticles were $\mathrm{HA}$ and $\mathrm{Si}$, while other ions typically present in lake waters, such as $\mathrm{SO}_{4}^{2-}$ and $\mathrm{Ca}^{2+}$, did not significantly affect the $\mathrm{P}$ removal efficiency. In particular, single-ion experiments showed that $\mathrm{P}$ adsorption by $\mathrm{Fe}$ particles was significantly reduced at high $\mathrm{HA}$ concentrations $(35.5 \mathrm{mg} / \mathrm{L})$. On the contrary, $\mathrm{Si}$ suppressed $\mathrm{P}$ adsorption at several high concentrations tested $(10,25$ and $50 \mathrm{mg} / \mathrm{L})$, but showed no significant effect at the lowest concentration $(5 \mathrm{mg} / \mathrm{L})$.

\section{ACKNOWLEDGMENTS}

This work was supported by Junta de Andalucía projects P10-RNM-6630 and P11-FQM-7074 (Proyectos de Excelencia, Spain) and MINECO MAT 2010-15101, MAT 2013-44429-R project (Spain).

\section{REFERENCES}

BALISTRIERI, L. S. \& J. W. MURRAY. 1982. The adsorption of $\mathrm{Cu}, \mathrm{Pb}, \mathrm{Zn}$, and $\mathrm{Cd}$ on goethite from major ion seawater. Geochimica et Cosmochimica Acta, 46: 1253-1265.

BORGGAARD, O. K., S. S. JORGENSEN, J. P. MOBERG \& B. RABEN-LANGER. 1990. Influence of organic matter on phosphate adsorption by aluminium and iron oxides in sandy soils. Journal of Soil Science, 41: 443-449.

BORGGAARD, O. K., B. RABEN-LANGER, A. L. GIMSING \& B. W. STROBEL. 2005. Influence of humic substances on phosphate adsorption by aluminium and iron oxides. Geoderma, 127: 270279.

BOUKHALFA, CH. 2010. Sulfate removal from aqueous solutions by hydrous iron oxide in the presence of heavy metals and competitive anions. Macroscopic and spectroscopic analyses. Desalination, 250: 428-432.

CHANG, C. M., Y. J. WANG, C. LIN \& M. K. WANG. 2004. Novel predicting methods for the removal of divalent metal ions by magnetite/amorphous iron oxide composite systems. Colloids and Surfaces A: Physicochemical and Engineering Aspects, 234: 1-7.

CORNELL, R. M. \& U. SCHWERTMANN. 1996. The Iron Oxides: Structure, Properties, Reactions, Occurrence and Uses, Wiley-VCH Verlag GmbH \& Co.KGaA. Weinheim.

DE VICENTE, I., F. Ø. ANDERSEN \& H. S. JENSEN. 2008. Factors affecting phosphate adsorption to aluminum in lake water: implications for lake restoration. Science of the Total Environment, 389: 29-36.

DE VICENTE, I., A. MERINO-MARTOS, L. CRUZPIZARRO \& J. DE VICENTE. 2010. On the use of magnetic nano and microparticles for lake restoration. Journal of Hazardous Materials, 181: 375381.

DE VICENTE, I., A. MERINO-MARTOS, F. GUERRERO, V. AMORES \& J. DE VICENTE. 2011. Chemical interferences when using high gradient magnetic separation for phosphate removal: Consequences for lake restoration. Journal of Hazardous Materials, 192: 995-1001.

DIXON, D. R. 1984. Colour and turbidity removal with reusable magnetite particles. VII. A colloid chemistry study of the effect of inorganic ions on the efficiency of clarification. Water Research, 18: 529-534.

EGEMOSE, S., I. DE VICENTE, K. REITZEL, M. R. FLINDT, F. Ø. ANDERSEN, T. L. LAURIDSEN, M. S $\theta$ NDERGAARD, E. JEPPESEN \& H. 
S. JENSEN. 2011. A changed cycling of P, N, $\mathrm{Si}$, and DOC in Danish Lake Nordborg after aluminum treatment. Canadian Journal of Fisheries and Aquatic Sciences, 68: 842-856.

GAO, Y. \& A. Mucci. 2003. Individual and competitive adsorption of phosphate and arsenate on goethite in artificial seawater. Chemical Geology, 199: 91-109.

GEELHOED, J. S., T. Hiemstra \& W. H. VAN RIEMSDIJKV. 1997. Phosphate and sulfate adsorption on goethite: Single anion and competitive adsorption. Geochimica et Cosmochimica Acta, 61: 2389-2396.

GERKE, J. \& R. HERMANN. 1992. Adsorption of Orthophosphate to Humic-Fe-Complexes and to Amorphous Fe-Oxide. Z Pflanzenernaehr Bodenkd, 155: 233-236.

GIBBS, M. \& D. ÖZKUNDAKCI. 2011. Effects of a modified zeolite on $\mathrm{P}$ and $\mathrm{N}$ processes and fluxes across the lake sediment-water interface using core incubations. Hydrobiologia, 661: 21-35.

GIRGINOVA, P. I., A. L. DANIEL-DA-SILVA, C. B. LOPES, P. FIGUEIRA, M. OTERO, V. S. AMARAL, E. PEREIRA \& T. TRINDADE. 2010. Silica coated magnetite particles for magnetic removal of $\mathrm{Hg}^{2+}$ from water. Journal of Colloid and Interface Science, 345: 234-240.

HARTIKAINEN, H., M. PITKÄNEN, T. KAIRESALO \& L. TUOMINEN. 1996. Co-occurrence and potential chemical competition of phosphorus and silicon in lake sediment. Water Research, 1354: 2472-2478.

HSU, J. C., C. J. LIN, C. H. LIAO \& S. T. CHEN. 2008. Evaluation of the multiple-ion competition in the adsorption of $\mathrm{As}(\mathrm{V})$ onto reclaimed ironoxide coated sands by fractional factorial design. Chemosphere, 72: 1049-1055.

HUPFER, M. \& S. HILT. 2008. Lake restoration. In: Encyclopedia of Ecology. S.E. Jørgensen \& B.D. Fath (eds.): 2080-2093. Elsevier. Oxford.

ILLÉS, E. \& E. TOMBÁCZ. 2004. The role of variable surface charge and surface complexation in the adsorption of humic acid on magnetite. Colloids Surfaces A: Physicochemical Engineers Aspects, 230: 99-109.

ILLÉS, E. \& E. TOMBÁCZ. 2006. The effect of humic acid adsorption on $\mathrm{pH}$-dependent surface charging and aggregation of magnetite nanoparticles. Journal of Colloid and Interface Science, 295: 115-123.
JEPPESEN, E., M. SØNDERGAARD, H. S. JENSEN \& A. M. VENTÄLA. 2009. Lake and reservoir management. In: Encyclopedia of Inland waters. G.E. Likens (ed.): 295-309. Elsevier. Oxford.

KARAPINAR, N. 2009. Application of natural zeolite for phosphorus and ammonium removal from aqueous solutions. Journal of Hazardous Materials, 170: 1186-1191.

KENNEDY, R. \& G. COOKE. 1982. Control of Lake Phosphorus with Aluminum Sulfate: Dose Determination and Application Techniques. Water Research Bulletin, 18: 389-395.

KIM, E. K. \& H. W. WALKER. 2001. Effect of cationic polymer additives on the adsorption of humic acid onto iron oxide particles. Colloids and Surfaces A: Physicochemical Engineering Aspects, 194: 123-131.

KOROLEFF, F. 1983. Determination of nutrients. In: Method of Seawater Analysis. K. Grasshof, M. Ehrhardt \& K. Kremling (eds.): 125-187, Verlag Chemie. Weinheim, New York.

MENG, X., S. BANG \& G. P. KORFIATIS. 2000. Effects of silicate, sulfate, and carbonate on arsenic removal by ferric chloride. Water Research, 34: 1255-1261.

MERINO-MARTOS, A., J. DE VICENTE, L. CRUZPIZARRO \& I. DE VICENTE. 2011. Setting up High Gradient Magnetic Separation for combating eutrophication of inland waters. Journal of Hazardous Materials, 186: 2068-2074.

MURPHY, J. \& J. P. RILEY. 1962. A modified single solution method for the determination of phosphate in natural waters. Analytica Chimica Acta, 27: 31-36.

PANTHER, J. G., P. R. TEASDALE, W.W. BENNET, D. T. WELSH \& H. ZHAO. 2011. Comparing dissolved reactive phosphorus measured by DGT with ferrihydrite and titanium dioxide adsorbents: Anionic interferences, adsorbent capacity and deployment time. Analytica Chimica Acta, 698: 20-26.

REITZEL, K., J. HANSEN, F. ø. ANDERSEN, K. S. HANSEN \& H. S. JENSEN. 2005. Lake restoration by dosing aluminum relative to mobile phosphorus in the sediment. Environmental Science and Technology, 39: 4134-4140.

REITZEL, K., H. S. JENSEN, M. R. FLINDT \& F. $\varnothing$. ANDERSEN. 2009. Identification of dissolved nonreactive phosphorus in freshwater by precipitation with aluminum and subsequent ${ }^{31} \mathrm{P}$ NMR analyses. Environmental Science and Technology, 43(14): 5391-5397. 
REITZEL, K., H.S. JENSEN \& S. EGEMOSE. 2013a. pH dependent dissolution of sediment aluminum in six Danish lakes treated with aluminum. Water Research, 47: 1409-1420.

REITZEL, K., S. LOTTER, M. DUDKE, S. EGEMOSE, H. S. JENSEN \& F. Ø. ANDERSEN. 2013b. Effects of Phoslock treatment and chironomids on the exchange of nutrients between sediment and water. Hydrobiologia, 703: 189-202.

REITZEL, K., F. Ø. ANDERSEN, S. EGEMOSE \& H. S. JENSEN. 2013c. Phosphate adsorption by lantanum modified bentonite clay in fresh and brackish water. Water Research, 47: 2787-2796.

ROBB, M., B. GREENOP, Z. GOSS, G. DOUGLAS \& J. ADENEY. 2003. Application of Phoslock, an innovative phosphorus binding clay, to two Western Australian waterways: preliminary findings. Hydrobiologia, 494: 237-243.

ROSS, G., F. HAGHSERESHT \& T. E. CLOETE. 2008. The effect of $\mathrm{pH}$ and anoxia on the performance of Phoslock, a phosphorus binding clay. Harmful Algae, 7: 545-550.

SCHINDLER, P. W. 1990. CO-adsorption of metal ions and organic ligands: Formation of ternary surface complexes. In: Mineral-water interface geochemistry. Reviews in Mineralogy. M. A. Hochella \& A. F. White (eds.): 281-309.

SIBANDA, H. M. \& S. D. YOUNG. 1986. Young Competitive adsorption of humus acids and phosphate on goethite, gibbsite and two tropical soils. Journal of Soil Science, 37: 197-204.
SIGG, L. \& W. STUMM. 1981. The interactions of anions and weak acid with the hydrous goethite $(\alpha$ FeOOH) surface. Colloids Surface, 2: 101-117.

SMELTZER, E., R. A. KIRN \& S. FISKE. 1999. Long-term water qualityand biological effects of alum treatment of lake Morey, Vermont. Lake Reservoir Management, 15(3): 173-184.

SMITH, V. H. 2009. Eutrophication. In: Encyclopedia of Inland Waters. G. E. Likens (ed.): 61-73, Elsevier. Oxford.

STACHOWICZ, M., T. HIEMSTRA \& W. H. VAN RIEMSDIJK. 2008. Multi-competitive interaction of As (III) and As (V) oxyanions with $\mathrm{Ca}^{2+}, \mathrm{Mg}^{2+}$, $\mathrm{PO}_{4}^{3-}$, and $\mathrm{CO}_{3}^{2-}$ ions on goethite. Journal of Colloid and Interface Science, 320: 400-414.

WELCH, E. B. \& G. D. COOKE. 1999. Effectiveness and longevity of phosphorus inactivation with alum. Lake Reservoir Management, 15: 5-27.

ZHANG, Y., Y. CHEN, P. WESTERHOFF \& J. CRITTENDEN. 2009a. Impact of natural organic matter and divalent cations on the stability of aqueous nanoparticles. Water Research, 43: 4249-4257.

ZHANG, G., H. Liu, R. LIU \& J. QU. 2009b. Removal of phosphate from water by a Fe-Mn binary oxide adsorbent. Journal of Colloid and Interface Science, 335: 168-174.

ZHANG, X., H. NIU, Y. PAN, Y. SHI \& Y. CAI. 2011. Modifying the surface of $\mathrm{Fe}_{3} \mathrm{O}_{4} / \mathrm{SiO}_{2}$ magnetic nanoparticles with $\mathrm{C}_{18} / \mathrm{NH}_{2}$ mixed group to get an efficient sorbent for anionic organic pollutants. Journal of Colloid and Interface Science, 362: 107-112. 